Original Article

\title{
FORMULATION AND EVALUATION OF CRACK CREAM FROM PLANT EXTRACTS
}

\author{
VIRENDRA V. PATIL ${ }^{1}$, YOGESH S. THORAT ${ }^{1}$, NAGESH S. KOTE ${ }^{1}$, AVINASH H. HOSMANI ${ }^{2}$ \\ 1Department of Pharmaceutics, D. S. T. S. Mandal's College of Pharmacy, Solapur, Maharashtra, India, ${ }^{2}$ Department of Pharmaceutics, \\ Government College of Pharmacy, Ratnagiri \\ Email: virendra4151@gmail.com
}

Received: 18 Jan 2020, Revised and Accepted: 21 Mar 2020

\begin{abstract}
Objective: The main aim of our research was to develop an anti-cracked heels cream formulation consisting of Hedychium Spicatum, Aloe barbadensis, Azadirachta indica for the treatment of cracked heels.

Methods: An anti-cracked heels cream formulation consisting of Hedychium Spicatum, Aloe barbadensis, Azadirachta indica extracts was prepared. Microbiological studies were performed the safety of materials used in the formulation.

Results: The developed cream consisting of Hedychium Spicatum, Aloe barbadensis, Azadirachta indica was found to be safe and effective for the treatment of cracked heels.

Conclusion: It can be concluded that herbal creams without side effects having anti-inflammatory property can be used as the provision of a barrier to protect the skin.
\end{abstract}

Keywords: Hedychium Spicatum, Aloe barbadensis, Azadirachta Indica

(c) 2020 The Authors. Published by Innovare Academic Sciences Pvt Ltd. This is an open access article under the CC BY license (http://creativecommons.org/licenses/by/4.0/) DOI: http://dx.doi.org/10.22159/ijcpr.2020v12i3.38322. Journal homepage: https://innovareacademics.in/journals/index.php/ijcpr

\section{INTRODUCTION}

The skin on the feet tends to become drier as there are no any oil glands present. This dryness causes the skin to crack. Lack of moisturization, over exposure to pollution and a few medical conditions like eczema, diabetes, thyroid, and psoriasis cause dry and cracked feet. Hedychium spicatum Buch Ham (Family: Zingiberaceae) is commonly known as Spiked ginger lily, has a rich history of use in India. It is a perennial rhizomatous herb, commonly found in Himalayas at altitudes 3500-7500 ft. It has been valued in the Traditional. The rhizome extract has been reported to contain resins, saccharides, albumen volatile oil, starch, organic acids and glycosides. This has been advocated for blood purification and coverings of bronchitis, indigestion, eye disease and inflammations. A number of beneficial effects of burn plants are reported, including wound and burn healing, antifungal, and anti-inflammatory properties.

Azadirachta indica, (Family: Meliaceae) commonly known as nimbin nimbidin, nimbolide, and limonoids commonly found in India, Pakistan, Bangladesh, and Nepal. Azadirachta indica have antifungal and antibacterial activities. Biological and pharmacological activities have been reported including antibacterial, antifungal, and antiinflammatory [1]. Cream contains medicament dissolved or suspended in water removable or emollient bases, classified as water-in-oil/oil-in-water and intended for application on the skin or accessible mucosa to supply localized and sometimes systemic effects at the location of the application. The function of skin cream is to guard the skin against harshness from the environment and any dry conditions of the skin. A skin cream should aid the skin in completing its normal functions that's restoring moisture to dry skin, allowing the elimination of waste through the pores. The cooling of the body by evaporation of water (perspiration) and radiation, thus aiding within the maintenance of the traditional blood heat [2].

\section{MATERIALS AND METHODS}

\section{Materials}

Hedychium Spicatum purchased from DKC AGROTECH PVT. LTD Delhi, Aloe barbadensis, Azadirachta indica, sodium lauryl sulphate, methylparaben, glycerine, span80, beeswax was obtained from laboratories.

\section{Methods}

\section{Extraction of hedychium spicatum}

Five hundred grams coarsely powdered was placed in $1000 \mathrm{ml}$ of double-distilled water and five hundred $\mathrm{ml}$ of ethanol, respectively, in two separate closed flasks for $24 \mathrm{~h}$, shaking first and keep it for 6 $\mathrm{h}$ and then allowed to stand for $18 \mathrm{~h}$. The sol ${ }^{\mathrm{n}}$ was filtered and the filtrates were then vaccum dried. The yields of aqueous and ethanolic extract were $7 \%$ and $4 \%$, respectively. They were stored in a refrigerator at $-20^{\circ} \mathrm{C}$ until further use [3].

\section{Extraction of Aloe barbadensis}

Samples were kept frozen $\left(-40^{\circ} \mathrm{C}\right)$ and protected from light until the analytical procedure took place. The aloe vera used for extractions measured between 40 and $60 \mathrm{~cm}$ in length and were taken from 2year old plants. Whole leaves were cleaned by washing them individually with distilled water and water with $0.5 \%$ chlorine. The margins and spikes were removed before slicing the leaf. The cortex was separated from the parenchyma. Filets were washed thoroughly with distilled water to remove the exudates from surfaces. Fresh aloe filets were stored for no longer than $1 \mathrm{~h}$ at-180C prior to lyophilisation [4].

\section{Extraction of Azadirachta indica}

Azadirachta indica leaf extract was used the ease of availability and its medicinal property. Fresh leaves were collected. They were surface cleaned with running water to rid of debris and other contaminated organic contents, followed by double DW and air dried at R temperature. About $20 \mathrm{gm}$ of finely cut leaves were kept in a beaker containing $200 \mathrm{ml}$ double DW and boiled for $30 \mathrm{~min}$. The extract was cooled down and filtered with Whatman filter paper no.1 and the extract was stored at $40 \mathrm{C}$ for further use [5].

\section{Formulation of cream}

Composition of all formulations of moisturizing cream as shown in table 1. 
Table 1: Composition of all formulations of moisturizing cream

\begin{tabular}{lllll}
\hline S. No. & Ingredient & Formulation (F1) & Formulation (F2) \\
\hline 1 & Hedychium Spicatum & $2 \mathrm{gm}$ & $2 \mathrm{gm}$ & Formulation (F3) \\
2 & Aloe barbadensis & $2 \mathrm{gm}$ & $1.50 \mathrm{gm}$ & $1 \mathrm{gm}$ \\
3 & Azadirachta indica & $1 \mathrm{gm}$ & $1 \mathrm{gm}$ & $1 \mathrm{gm}$ \\
4 & Sodium lauryl sulphate & $1 \mathrm{gm}$ & $0.50 \mathrm{gm}$ & $1 \mathrm{gm}$ \\
5 & Methyl paraben & $0.50 \mathrm{gm}$ & Q.S & $0.50 \mathrm{gm}$ \\
6 & Glycerin & $\mathrm{QS}$ & Q.S & QS \\
7 & Span 80 & $\mathrm{QS}$ & $3 \mathrm{gm}$ & QS \\
8 & Bees wax & $2 \mathrm{gm}$ & & $4 \mathrm{gm}$ \\
\hline
\end{tabular}

\section{Preparation of cream formulation}

White Bees Wax melted in a beaker. The temperature of oil phase maintained between $65-70{ }^{\circ} \mathrm{C}$.

In this weighed Hedychium Spicatum, Aloe barbadensis, Azadirachta indica, Sodium lauryl sulphate, Methylparaben, Glycerin, Span 80. Oil phase was slowly added to the aqueous phase with continuous stirring. The emulsion was cooled to temperature to make a semisolid cream base. pH of cream kept between 4.5-7.

\section{Evaluation of crack cream [6-11]}

\section{Test for thermal stability}

The formulated cream was inserting into a glass bottle with the assistance of spatula and taped to settle to rock bottom. Filled up to $2 / 3$ rd capacity of the bottle and insert the plug and tighten the cap. Fitted was kept correct inside the incubator at $4{ }^{\circ} \mathrm{c}$ for $48 \mathrm{~h}$. The sample passed the test, if on removal from the incubator shows no other phase separation [7]

\section{Test for microbial growth in formulated creams}

The formulated crack creams were inoculated on the petri plates of agar media by using the streak plate method and an impact was prepared by omitting the crack cream. The petri plates were placed into the incubator and are incubated at $37^{\circ} \mathrm{c}$ for $24 \mathrm{~h}$. After the time period plates were taken out and check the microbial growth by comparing it with the control [8].

\section{Spreadability}

The spreadability of samples was determined. Take $0.5 \mathrm{~g}$ crack cream formulation was placed within a circle of $1 \mathrm{~cm}$ diameter on a glass slide over which a second glass plate was placed. A weight of $500 \mathrm{~g}$ was allowed to rest on the upper glass slide for $5 \mathrm{~min}$. Spreadability refers to the area covered by a fixed amount of crack cream sample after the uniform spread of the sample on the glass slide. The increase in the diameter because of the spreading of the test crack cream formulation was noted. Average of 3 determinations was noted [9].

\section{Irritancy}

Test Mark a neighborhood (1sq. cm) on the left dorsal surface. The cream was applied to the required area and time was noted. Irritancy, erythema, edema, was checked if any for normal intervals up to $24 \mathrm{~h}$ and reported [10].

\section{Washability}

A small amount of cream applied available and washed under running water [10].

\section{Viscosity}

Brookfield Synchro-Lectric Viscometer with helipath stand was used for viscosity studies. The sample $(10 \mathrm{~g})$ was taken in a beaker and was allowed to equilibrate for $5 \mathrm{~min}$ before measuring the reading using a T-D spindle at $10,20,30,50,60,100 \mathrm{rpm}$. Each speed the corresponding reading on the viscometer was noted. The spindle speed was successively lowered and the corresponding reading was noted. The measurements were carried in 3 times at ambient temperature. Direct multiplication of the readings with factors given in the Brookfield viscometer catalogue gave the viscosity in cps. Average of three triplicates was computed [10].

\section{$\mathrm{PH}^{\mathrm{H}} \mathrm{Of}$ the cream}

The $\mathrm{pH}$ of the $10 \% \mathrm{w} / \mathrm{v}$ cream suspension was determined at $25{ }^{\circ} \mathrm{C}$ using a $\mathrm{pH}$ meter, standardized using $\mathrm{pH} 4.0$ and 7.0 standard buffers before use and average of triplicates were determined [11].

\section{Phase separation}

This test was conducted because of no any phase separation in the formulated cream. The formulated crack cream was kept intact during a closed container at $25-100{ }^{\circ} \mathrm{C}$ not expose to light. Phase separation was observed every $24 \mathrm{~h}$ for $1 \mathrm{mo}$. Daily changes in phase separation were checked [11].

\section{Moisture absorption studies}

$10 \mathrm{mg}$ of crack cream was taken on a watch glass. A $100 \mathrm{ml}$ beaker was taken with full of water and was kept in a desiccators without adsorbents and allowed to get saturated. Watch glass with cream was introduced into the desiccators. It was left for $24 \mathrm{~h}$ [11]

\section{RESULTS AND DISCUSSION}

\section{Physical properties}

The physical properties and all formulated crack cream were observed by its color, Odor and texture. The F2 batch Color was light brown, Odor was pungent and texture was smooth-non-sticky cream like.

\section{Test for thermal stability}

Thermal stability of the crack cream was determined by the humidity chamber controlled at $60-70 \% \mathrm{RH}$ and $37{ }^{\circ} \mathrm{C}$. Finally, F2 formulation stable and no oil separation was observed.

\section{Test for microbial growth in formulated creams}

The formulated crack creams were inoculated on the petri plates of agar media by using streak plate method and an impact was prepared by omitting the crack cream. The plates were placed in the incubator and are incubated at $37^{\circ} \mathrm{C}$ for $24 \mathrm{~h}$. After the time period, plates were taken out and check the microbial growth of gram-positive (Bacillus) and gram-negative (E. coli) by comparing it with the control and reported that in F1, F2 and F3 batch Bacillus and E-coli growth was absent.

\section{Spreadability}

The spreadability of all crack cream formulations was determined and it was observed that formulation F2 has greater spreadability as compared to other batches as well as the prototype formulation as shown in table 2 .

\section{Irritancy}

In this formulation, F2 shows no inflammation, redness, edema and irritation during irritancy studies. These formulations of crack cream are safe to use for skin.

\section{Washability}

A small amount of cream applied on the skin surface and washed under running water. The washability of all formulations was easily washable with water. No any stickiness on the skin.

\section{Viscosity}

Viscosities of all the formulations were noted and found in the range of $1896 \pm 4.56$ to $2418 \pm 6.75$ CPS at $10 \mathrm{rpm}$. All the formulations were showed pseudoplastic flow shown in table 2. 
Table 2: Evaluation parameters for the all crack cream formulations

\begin{tabular}{llll}
\hline Formulation code & pH (mean \pm SD) & Viscosity at 10 rpm (CPS) (mean \pm SD) & Spreadability (mean \pm SD) \\
\hline F1 & $7.21 \pm 0.185$ & $1896 \pm 4.56$ & $4.72 \pm 0.10$ \\
F2 & $7.20 \pm 0.189$ & $2089 \pm 5.89$ & $6.15 \pm 0.16$ \\
F3 & $7.31 \pm 0.244$ & $2418 \pm 6.75$ & $6.95 \pm 0.10$ \\
\hline
\end{tabular}

\section{$\mathrm{PH}^{\mathrm{H}}$ of the cream}

$\mathrm{pH}$ of all the formulations was found to be between $7.21 \pm 0.185$ to7.31 \pm 0.244 that is within the range, which are presented in table 2 .

\section{Phase separation}

The formulated crack cream was kept intact during a closed container at $25-100{ }^{\circ} \mathrm{C}$, not exposed to light. Phase separation was observed every $24 \mathrm{~h}$ for $1 \mathrm{mo}$. In this crack cream, all formulations shown no phase separation was observed.

\section{Moisture absorption studies}

$10 \mathrm{mg}$ of herbal cream was taken on a watch glass. A beaker was taken with full of water and was kept in a desiccators without adsorbents and allowed to get saturated. Watch glass with cream was introduced into the desiccators. It was left for $24 \mathrm{~h}$. After $24 \mathrm{~h}$ the moisture absorption was noted that moisture was not absorption.

\section{DISCUSSION}

Prepared crack cream formulations were subjected to various assessment parameters and the findings obtained were within the limits. All the formulations were found to be alkaline in $\mathrm{pH}$ test. All the formulations showed psuedoplastic flow on the basis of viscosity. The spreadability of formulation F2 is greater as compared to other formulations as well as the prototype formulation. Amongst all of the formulations, only F1, F3 and F2 showed better thermal stability at $20{ }^{\circ} \mathrm{C}, 30{ }^{\circ} \mathrm{C}$ and $40{ }^{\circ} \mathrm{C}$. The $\mathrm{F} 2$ was selected as an optimized formulation on the basis of results of spreadability and viscosity.

\section{ACKNOWLEDGMENT}

The authors wish to thank D. S. T. S. MANDALS COLLEGE OF PHARMACY for providing facilities and carry out the research work and also to Prof. DR. Yogesh thorat for their valuable support and guidance and also thankful to Nagesh kote, sachin yanjane, sumesh paralkar.

\section{FUNDING}

Nil

\section{AUTHORS CONTRIBUTIONS}

All the authors have contributed equally.

\section{CONFLICT OF INTERESTS}

Declare none

\section{REFERENCES}

1. stylecraze.com/articles/simple-home-remedies-for-crackesheels/\#gref. [Last accessed on 10 Dec 2019]

2. https://www.slideshare.net/anupriyaSinghRajpoot/pharmace utical-cream. [Last accessed on 10 Dec 2019]

3. Shivani Ghildiyal, Manisha K Gautam, Vinod K Joshi, Raj K Goel. Pharmacological evaluation of extraction of Hedychium spicatum (Ham-ex-Smith) rhizome, US national labrary of medical. National Institute Health 2012;31:117-2.

4. Muñoz OM, Leal X, Quitral V, Cardemil L. Extraction, characterization and properties of the gel of burn plant (Aloe barbadensis miller) cultivated in chile. Med Aromat Plants 2015;4:3.

5. Shakeel Ahmed, Saifullah, Mudasir Ahmad, Babu Lal Swami, Saiqa Ikram. Green synthesis of silver nanoparticles using Azadirachta Indica aqueous leaf extract. J Radiat Res Appl Sci 2016;9:1-7.

6. Akash S Mali, Karekar P, Yadav AV. Formulation and evaluation of multipurpose herbal cream. Int J Sci Res 2017;1:1-18.

7. Mei X Chen, Kenneth S Alexander, Gabriella Baki. Formulation and evaluation of antibacterial creams and gels containing metal ions for topical application. J Pharm 2016. Doi:10.1155/2016/5754349

8. Abhay Prakash Mishra. Available from: https://www.researchgate.net/publication/289835679_Healt h_Promoting_Phytochemicals_Their_Concentration_and_Antiox idant_Activity_of_Wild_Edible_Fruits_of_Uttarakhand_India?ev= auth_pub. [Last accessed 15 Dec 2019].

9. Anuradha Keshwar, Unmesh Keshwar, Ashwini Deogirkar, SS Dhurde, Veena Deo, BK Shrikhande. Formulation development and evaluation of cream containing natural essential oils having mosquito repellent property. World J Pharm Pharm Sci 2018;8:1586-93.

10. NR Patel, HU Momin, RL Dhumal, KL Mohite. Prepara prepartion and evaluation of multipurpose herbal cream. Adv J Pharm Life Sci Res 2017;5:27-32.

11. Ashwini SD, Somishwar SK, Shweta SS. Formulation and evaluation of vanishing herbal cream of crude drugs. Am J Ethnomed 2014;1:313-8. 